\title{
KONVERSI LIMBAH UBI KAYU MENJADI BIOETANOL SEBAGAI SUMBER ENERGI ALTERNATIF UNTUK WARGA PASCA GEMPA DI LOMBOK UTARA
}

\author{
Rahmat Sabani ${ }^{*}$, Sukmawaty, Hary Kurniawan, dan Amuddin \\ Program Studi Teknik Pertanian Fakultas Teknologi Pangan dan Agroindustri \\ Universitas Mataram \\ ${ }^{*}$ Korespondensi: rahmat.sabani@unram.ac.id
}

Diterima 6 November 2018 / Disetujui 7 Desember 2018

\begin{abstract}
ABSTRAK
Bencana alam gempa bumi yang mengumcang pulau Lombok khususnya Lombok Utara telah menghancurkan penghidupan warga, memberikan dampak pada sumberdaya yang dimiliki warga termasuk akses yang sangat terbatas terhadap sumber energi untuk kehidupan senari-hari. Limbah organik yang melimpah adalah potensi sebagai sumber biomassa untuk konversi bioenergi yang memberikan peluang akses warga terhadap energi yang murah. Telah dilakukan kegiatan untuk melatih warga yang tergabung dalam kelompok pengelola TPS di Desa Sigar Penjalin untuk dapat memanfaatkan limbah organik sebagai sumber biomassa untuk menghasilkan bioetanol. Metode biokonversi dengan teknologi fermentasi konvensional menggunakan ragi dan distilasi sistem batch telah diaplikasikan pada konversi limbah ubi kayu. Melalui kegiatan ini telah diperoleh bioetanol sebanyak $580 \mathrm{ml}$ untuk setiap dua jam proses distilasi dari bahan limbah ubi kayu yang difermentasi selama empat hari, dengan kadar etanol mencapai 90\%-95\%. Hasil bioetanol yang diperoleh melalui kegiatan ini dapat menjadi sumber energi dan digunakan oleh warga untuk memasak dan lampu penerangan sederhana pada masa recovery pasca gempa serta mengembangkan penyediaan energi berbasis limbah organik dan peluang pengembangan usaha.
\end{abstract}

Kata kunci: limbah organik, bioetanol, energi alternatif

\section{PENDAHULUAN}

Sampah telah menjadi isu penting dalam pembangunan daerah. Pengelolaan sampah yang dilakukan oleh masyarakat, dunia usaha dan pemerintah belum dapat menjawab persoalan pengelolaan sampah, terutama di perkotaan. Berbagai persoalan terjadi disebabkan oleh belum tetanganinya sampah yang semakin banyak, sejalan dengan pertumbuhan penduduk, meluasnya kawasan pemukiman, dan kegiatan ekonomi. Sementara pada sisi lain pengelolaan sampah yang dilakukan masih terbatas pada pemindahan dan penempatan sampah di Tempat Pembuangan Akhir (TPA). Belum banyak dilakukan inovasi untuk penanganan dan pengelolaan sampah yang dapat menjawab persoalan semakin menumpuknya sampah. 
Pengelolaan Sampah di Kabupaten Lombok Utara telah diatur melalui peraturan Bupati Lombok Utara nomor 3 tahun 2017 tentang Petunjuk Pelaksanaan Pengelolaan Sampah, yang merupakan Perubahan atas Peraturan Bupati Lombok Utara nomor 7 tahun 2014, yang mengatur tentang pemilahan, pengumpulan, pengangkutan, pengelolaan; dan pemrosesan akhir sampah. Kondisi saat ini pengelolaaan persampahan menghadapi banyak tekanan terutama akibat semakin besarnya timbuan sampah yang dihasilkan masyarakat baik produsen maupun konsumen. Hal ini semakin berat dengan konsep pengelolaan paradigma lama yang mengandalkan kegiatan pengumpulan, pengangkutan, dan pembuangan, yang selain membutuhkan anggaran yang besar, dan secara teknis seringkali tidak efektif, yang bila tidak tersedia akan menimbulkan banyak masalah operasional seperti sampah tidak terangkut, fasilitas yang tidak memenuhi syarat, cara pengoperasian fasilitas yang tidak mengikuti teknis.

Diperkirakan masyarakat lombok utara memproduksi sampah industri dan rumah tangga mencapai hampir seratus ton perhari, dari sebanyak itu sekitar 50 ton lebih diproduksi oleh warga dari kecamatan Pemenang khususnya dari kawasan wisata Tiga Gili dan pasar tradisional Pemenang. Berbagai cara tengah diupayakan salah satunya membentuk Unit Pelaksana Teknis Daerah (UPTD) pengelolaan sampah di semua kecamatan Gumi Tioq Tata Tunaq. Sementara dari wilayah kecamatan Bayan, kayangan dan Gangga dan terutama dari wilayah Tanjung, ibukota kabupaten dihasilkan Sampah hingga mencapai 40 ton lebih sampah kering dan basah.

Pengelolaan sampah selama ini menggunakan pola pengelolaan/penanganan sampah setempat (individu) dan pengelolaan sampah terpusat. Penanganan setempat adalah penanganan yang dilaksanakan sendiri oleh penghasil sampah dengan menanam dalam galian tanah pekarangan atau dengan membakar. Sedangkan Pengelolaan Pesampahan secara terpusat adalah suatu proses atau kegiatan penanganan sampah yang dikoordinir oleh Dinas PU Tamben Kabupaten Lombok Utara di Wilayah kota Tanjung dan sekitarnya.

Selain persoalan sampah, masyarakat menghadapi persoalan dalam memenuhi kebutuhan energi yang semakin meningkat di tengah kecenderungan kelangkaan sumber energi yang bersumber dari energi fosil dan harga bahan bakar yang terus mengalami kenaikan. Masyarakat, utamanya masyarakat miskin dan berpenghasilan rendah cenderung semakin sulit mendapat bahan bakar sesuai kebutuhannya sehari-hari. Suatu upaya diperlukan untuk dikembangkan guna menjawab persoalan yang dihadapi masyarakat, khususnya terkait dengan persoalan sampah dan pemenuhan kebutuhan bahan bakar, terutama untuk masyarakat miskin dan berpenghasilan terbatas, serta untuk masyarakat yang memiliki keterbatasan akses terhadap bahan bakar (energi) untuk kebutuhannya sehari-hari. Upaya yang dapat ditempuh antara lain adalah melalui pendekatan keterpaduan antara upaya penanganan dan pengolahan sampah dengan upaya penyediaan bahan bahar yang bahan bakunya dari sampah. 
Bencana alam gempa bumi yang menguncang pulau Lombok khususnya Lombok Utara berdampak besar dan melumpuhkan perekonomian dan aktivitas warga, termasuk dalam memenuhi kebutuhan hidup sehari-hari, antara lain adalah akses warga terhadap kebutuhan pokok sehari-hari terhadap sumber energi.

Untuk itu, telah dilaksanakan kegiatan pengabdian pada masyarakat dalam bentuk pelatihan pembuatan bioetanol dari sampah organik. Sampah yang dipilih untuk menjadi sumber biomassa adalah limbah ubi kayu yang diperoleh dari tempat pembuangan sampah rumah tangga dan pasar di sekitar desa Sigar Penjalin, serta dari tempat penampungan sementara (TPS) yang berlokasi di desa Sigar Penjalin.

\section{METODE KEGIATAN}

Pendekatan yang dipergunakan pada kegiatan ini adalah pendekatan participatory andragogy, yaitu proses pelatihan yang melibatkan orang dewasa ke dalam struktur pengalaman belajar secara partisipatif. Asumsi dasar pendekatan ini adalah meliputi aspek konsep diri orang dewasa, pengalaman orang dewasa, kesiapan belajar, orientasi waktu dan arah belajar serta semangat berpartisipasi. Kunci penerapan pendekatan ini adalah membantu setiap peserta tertarik, aktif dan antusias terlibat secara partisipatif.

Metode yang digunakan pada kegiatan ini adalah metode belajar bersama berbasis pemecahan masalah (problem solving) secara partisipatif, dan eksperimental. Kegiatan ini dilaksanakan dengan tiga tahapan, yaitu; pertama, tahapan persiapan. Kegiatan pada tahapan ini adalah melakukan penentuan lokasi, jenis biomassa yang akan digunakan, penentuan peserta, persiapan dan setup distilator beserta kelengkapannya. Pada tahapan ini, dilakukan pengumpulan dan sortasi biomassa dari tumpukan sampah. Limbah organik yang dipilih adalalah limbah ubi kayu.

Tahap kedua, adalah penyampaian materi yang relevan untuk distilasi biomassa menjadi bioetanol. Materi yang disampaikan adalah teknik konversi biomassa menjadi bioetanol, teknik penanganan bahan, teknik separasi/ sortasi, dan teknik pengoperasian distilator type batch. Tahapan ini untuk memberikan pengetahuan kepada peserta tentang penanganan biomassa (limbah organik), teknologi konversi biomassa menjadi bioetanol dan mesin peralatan distilasi. Proses pada tahapan ini banyak dilakukan melalui study kasus dan problem solving. Materi narasumber berfungsi sebagai pengantar diskusi.

Selanjutnya tahapan ketiga adalah tahap eksperimentasi/percobaan. Tahapan ini adalah tahapan praktek konversi bahan dari limbah organik ubi kayu yang telah difermentasi. Mesin distilasi yang digunakan adalah mesin distilasi type batch dengan kapasitas $40 \mathrm{lt}$, hasil rancang bangun oleh salah seorang narasumber.

\section{HASIL DAN PEMBAHASAN}

Lima belas orang warga telah dilatih untuk dapat melakukan konversi limbah organik menjadi bioetanol (bioenergi). Mereka mendapatkan pengetahuan dan keterampilan untuk 
dapat memanfaatkan biomassa dari sampah organik. Pengetahuan dan keterampilan yang diperoleh antara lain adalah; pengetahuan tentang bahan biomassa yang dapat dijadikan sebagai bahan pembuatan bioetanol, teknik penanganan dan pengolahan limbah organik agar dapat dipergunakan sebagai bahan pembuatan bioetanol, teknik sortasi dan separasi biomassa untuk memperoleh biomassa yang dibutuhkan dan sesuai dengan persyaratan untuk dapat dikonversi menjadi bioetanol.Selain itu mereka juga mendapatkan pengetahuan dan keterampilan tentang proses konversi biomassa melalui tahapan fermentasi dan distilasi serta kondensasi. Mereka sangat antusias karena mendapatkan pengetahuan, wawasan dan keterampilan yang mengintegrasikan penanganan dan pengolahan sampah untuk memngurangi timbunan sampah, mendapatkan sumber energi (alternative) yang murah, dan peluang pengembangan usaha untuk sumber pendapatan dan peluang lapangan pekerjaan (wirausaha).

Penyampaian materi dan diskusi untuk masing-masing narasumber adalah 45 menit, sehingga total waktu penyampaian materi dan diskusi berlangsung selama sekitar 180 menit. Hasil evaluasi post test memberikan gambaran bahwa sebagaian besar yaitu sebanyak 12 orang peserta (80\%) memahami dengan baik materi yang disampaikan oleh narasumber, sebagian peserta yaitu sebanyak 3 orang (20\%) masih membutuhkan penjelasan tambahan dari narasumber untuk dapat memahami materi pelatihan. Materi yang dirasakan peserta membutuhkan penjelasan tambahan adalah tentang prinsip distilasi untuk menghasilkan bioetanol dan teknis pengoperasian distilator.

Hasil evaluasi pre test dan post tes menunjukkan bahwa peserta menyadari bahwa pengelolaan sampah selama ini yang dilakukan oleh kelompok masih belum sesuai dengan materi yang telah disampaikan oleh narasumber, namun beberapa inisiatif telah dilakukan untuk melakukan pemanfaatan sampah, yaitu kegiatan pemilahan sampah organik dan anorganik. Sampah an organik yang berupa gelas plastik dan botol plastik yang kemudian dijual kepada pedagang pengumpul. Saat ini kelompok telah memiliki mesih pencacah sampah plastik. Setelah mendapatkan penjelasan dari narasumber, kelompok merencanakan untuk mengolah sampah plastik yang akan dikonversi menjadi bahan bakar menggunakan gasifier. Direncanakan gasifier akan di rakit dan dibuat sendiri oleh kelompok dengan harapan mendapat pembinaan dari Tim Universitas Mataram. Terkait dengan hal ini, tim pengabdian telah menyanggupi untuk menjadikan kelompok sasaran sebagai kelompok binaan melalui kerjasama untuk keberlanjutan pembinaan.

Kegiatan pelatihan pada tahapan praktek berjalan sesuai dengan skenario, peserta didampingi narasumber dapat melaksanakan tahapan proses konversi limbah ubi kayu menjadi bioetanol. Proses konversi yang dilakukan terhadap bahan yang telah dicacah. Bahan tersebut kemudian dikeringkan hingga kadar air sekitar 16\%, hal ini dimaksudkan agar dapat disimpan sebagai cadangan bahan baku. Kemudian dimasukkan $25 \mathrm{~kg}$ bahan dalam wadah penampung, kemudian menambahkan air hingga mencapai volume 100 liter. Selanjutnya dilakukan 
pemanasan selama 0,5-1 jam, selanjutnya dilakukan pengadukan sampai menjadi bubur dan mengental. Bahan tersebut kemudian didinginkan, dan selanjutnya dimasukkan ke dalam tangki sakarifikasi. Sakarifikasi adalah proses penguraian pati menjadi glukosa

Setelah dingin, peserta memasukkan cendawan Aspergillus untuk memecah pati menjadi glukosa. Untuk menguraikan 100 liter bubur, ditambahkan 10 liter larutan cendawan Aspergillus atau $10 \%$ dari total bubur. Dalam banyak referensi menyebutkan bahwa konsentrasi cendawan mencapai 100-juta sel/ml. Sebelum digunakan, Aspergillus dikulturkan pada bubur yang telah dimasak untuk beradaptasi dengan sifat bubur. Cendawan berkembang biak dan bekerja mengurai pati. Sekitar dua jam bubur akan berubah menjadi dua lapisan, yaitu air dan endapan gula. Selanjutnya dilakukan pengadukan bahan yang sudah menjadi gula tersebut, kemudian dimasukkan ke dalam tangki fermentasi.

Pada proses ini bakteri Saccharomyces bekerja mengurai gula menjadi alkohol. Peserta kemudian menambahkan air untuk menjaga agar kadar gula tidak terlalu tinggi, karena pada kadar gula yang tinggi aktivitas mikroba tidak terlalu efektif. Penambhan gula diperlukan jika kadar gulanya rendah (dapat ditambahkan gula pasir). Kadar gula yang disukai bakteri ini berkisar antara $17-18 \%$. Selanjutnya tangki ditutup rapat untuk mencegah kontaminasi agar Saccharomyces bekerja loptimal dalam mengurai glukosa.

Proses fermentasi berlangsung dalam kondisi anaerob. Suhu pada proses fermentasi diupayakan pada 28-32 oC dengan $\mathrm{pH}$ sekitar 4,5-5,5. Setelah 2-3 hari, larutan pati berubah menjadi 3 lapisan. Lapisan terbawah berupa endapan protein, di atasnya air, dan etanol. Hasil fermentasi tersebut mengandung sekitar 6-12 \% etanol. Kemudian larutan etanol diekstrak menggunakan selang plastik melalui kertas saring berukuran 1 mikron untuk menyaring endapan protein.

Pada kegiatan praktek, peserta antusias mengikuti proses distilasi bahan limbah ubi kayu yang telah dipersiapkan dan telah difermentasi. Proses distilasi berjalan sesuai dengan proses yang direncanakan yang dipandu oleh narasumber. Untuk praktek ini digunakan cairan luluhan ubi kayu yang telah dicampur dengan air dengan perbandingan 50:50 yang sebelumnya telah difermentasi, sebanyak sekitar 30-40 liter. Suhu evaporator pada proses ini berada sampai pa

da kisaran sekitar sampai $80^{\circ} \mathrm{C}$. Suplay air pendingin untuk proses kondensasi berasal dari air sumur menggunakan mesin pompa listrik yang berada di lokasi TPS. Setelah proses distilasi berlangsung selama 1 jam operasi, diperoleh bioetanol sekitar $300 \mathrm{ml}$, setelah proses berlangsung selama 1 jam, operasi distilasi tetap dilanjutkan oleh peserta selama 1 jam, yang tetap didampingi oleh narasumber. Praktek ini berlangsung selama sekitar 2 jam, dan jumlah bioetanol yang diperoleh adalah sekitar $580 \mathrm{ml}$.

Pada pelaksanaan pelatihan ini, bioetanol yang dihasil diaplikasikan pada lampu dan kompor sederhana, dan diperoleh nyala api yang baik berwarna merah kebiruan. Hal ini menunjukkan bahwa bioetanol yang dihasilkan dari 
proses ini cukup baik dan dapat diaplikasikan untuk memasak.

\section{KESIMPULAN DAN SARAN}

\section{Kesimpulan}

Dari pelaksanaan kegiatan ini, dapat disimpulkan bahwa kegiatan ini memberikan manfaat yang sangat berarti bagi warga terutama kelompok sasaran, terutama karena pada masa rcovery pasca gempa keterbatasan akses masyarakat terhadap sumber energi yang terjangkau dan murah dapat disediakan oleh warga sendiri dengan memanfaatkan limbah organik yang tersedia dengan melimpah untuk dikonversi menjadi sumber energi alternative, guna memenuhi kebutuhan energi warga untuk memasak, penerangan dan mendukung pengembangan usaha. Hal ini akan bepengaruh pula pada pengurangan timbunan sampah untuk menjaga lingkungan hidup dari pencemaran.

\section{Saran}

Kegiatan ini perlu ditindaklanjuti melalui pendampingan untuk keberlanjutan hasil kegiatan, dalam bentuk kegiatan yang relevan untuk keberlanjutannya, utamanya terkait dengan pengelolaan sampah, pengembangan sumber energi alternatif untuk warga dan pengembangan wirausaha.

\section{DAFTAR PUSTAKA}

Badan Standarisasi Nasional (BSN), 1992, Standar Nasional Indonesia (SNI) 19-
2454-1992 tentang Tata cara Pengelolaan Teknik Sampah Perkotaan, Departemen Pekerjaan Umum, Jakarta

Dirjen migas, 2007. Penggunaan bahan bakar minyak di indonesia tahun 2000-2006, Jakarta

Kementerian Lingkungan Hidup, 1997, Undang-Undang RI Nomor 23 Tahun 1997, tentang Pengelolaan Lingkungan Hidup, Jakarta

Kementerian Lingkungan Hidup, 2008, Undang-Undang RI Nomor 18 Tahun 2008, tentang Pengelolaan Sampah, Jakarta

Kementerian Pekerjaan Umum. 2010. Modul Pengolahan Sampah Berbasis 3 R. Jakarta

Klanarong Sriroth1, Sittichoke Wanlapatit, and Kuakoon Piyachomkwan. Cassava Bioethanol. National Center for Genetic Engineering and Biotechnology (BIOTEC).Thailand. https://www.researchgate.net/publi cation/221923560_Cassava _Bioethanol

Pothiraj C, Arun A, dan Eyini. 2014. Simultaneous Saccharification and Fermentation ofCassava Waste for Ethanol Production. Biofuel Research Journal, 5(1): 196 202.https://www.biofueljournal.co m/article_8441_ffbe8fe808712c064 1b1b240122d4d1.pdf.

Rama, at al. 2007. Bioetanol Ubi Kayu Bahan Bakar Masa Depan, Agromedia Pustaka. Jakarta. 